\title{
Investigation of the microclimate of poultry houses and chemical composition of poultry litter, depending on the time of its accumulation in the cage batteries
}

\author{
A.P. Palii ${ }^{1}$, O.A. Naumenko ${ }^{1}$, O.I. Shkromada ${ }^{2}$, L.A. Tarasenko ${ }^{3}$, K.A. Rodionova ${ }^{4}$, O.L. \\ Nechyporenko ${ }^{2}$, V.V. Nechyporenko' ${ }^{2}$, L.Y. Ulko ${ }^{2}$, K.V. Ishchenko ${ }^{1}$, V.G. Prudnikov ${ }^{5}$, A.P. Paliy ${ }^{6}$ \\ A.V. Berezovskiy ${ }^{7}$ \\ ${ }^{1}$ Kharkiv National Technical University of Agriculture named after Petro Vasylenko, \\ Str. Alchevskih, 44, Kharkiv, 61002, Ukraine \\ ${ }^{2}$ Sumy National Agrarian University, Str. G. Kondratiev, 160, Sumy, 40021, Ukraine \\ ${ }^{3}$ Odessa State Agrarian University, Str. Panteleymonyvska, 13, Odessa, 65012, Ukraine \\ ${ }^{4}$ Luhansk National Agrarian University, Str. Slobozhanska, 68, Starobelsk, Lugansk region, 92700, Ukraine \\ ${ }^{5}$ Kharkiv State Veterinary Academy, Str. Academic 1, Mala Danylivka, Dergachi district, Kharkiv region, 62341, \\ Ukraine \\ ${ }^{6}$ National Scientific Center «Institute of Experimental and Clinical Veterinary Medicine», \\ Str. Pushkinska, 83, Kharkiv, 61023, Ukraine \\ ${ }^{7}$ Doctor of Veterinary Science, Professor, Professor of the Chair of Veterinary-sanitary Examination, Microbiology \\ and Zoohygiene and Food Safety and Quality, Sumy National Agrarian University, Business address: G. Kondratiev Str., \\ 160. Sumy, Ukraine, 40021. \\ E-mail: paliy.andriy@ukr.net
}

Received: 07.09.2019. Accepted: 07.10.2019

\begin{abstract}
One of the main reasons of the destabilization of the ecological environment around poultry farms is the widespread use of resource-consuming and environmentally irrational production processes and technological preparation, processing and disposal of poultry waste. Nowadays, cage batteries with a belt removal system are becoming more widespread in the poultry farming. However, the use of such equipment does not guarantee compliance with applicable veterinary and sanitary requirements for the content of harmful gases in the air of the poultry houses and its microbial contamination. This, in turn, has a negative impact on the state of the environment. In addition, the equipment designed for countries with a milder climate than in Ukraine does not support the designed regimes of its individual systems. Therefore, the study of the effect of the accumulation of the litter on the belts of the cage batteries on its humidity, chemical composition and microclimate in the poultry house, from the environmental point of view, remains an urgent problem. On the basis of complex studies, the kinetics of the drying of the litter on the belt conveyors of the cage batteries for keeping laying hens with built-in air ducts and without air ducts in different seasons, as well as the effect of the duration of the accumulation of the litter on the microclimate in the poultry house, microbial contamination and chemical composition of the litter have been studied. The study of the microclimate in the poultry house, depending on the time of accumulation of the litter on the conveyor belts, showed that with the increase in the time of accumulation of excrements in the air, the content of ammonia increased, and after 5 days of accumulation in the cold season its level began to exceed the maximum contamination level $(\mathrm{MCL})-15 \mathrm{mg}$ per $\mathrm{m}^{3}$ of the air. The amount of ammonia on the 7 th day of the litter accumulation in all poultry houses was 1.8-2.8 times greater $(P \leq 0.001)$ compared to the first day. The amount of carbon dioxide in the air increased by 1.142.00 times, but it never exceeded the MCL $-0.25 \%$. When studying the both types of cage batteries, 1.2-2.6 times the maximum contamination level of the air (220 thous. microbic units per $\mathrm{m}^{3}$ ) was established in the poultry houses. In the case of cage batteries without built-in ducts from the 1st to the 7th day of accumulation, microbial air contamination increased by 1.9 times in the cold season, and by 1.7 times - in the warm season; and on the 7th day it was 579 and 462 thous. microbic units per $\mathrm{m}^{3}$, respectively. When using the cage batteries with built-in ducts, microbial air contamination increased slightly: by 1.7 times in the cold season and 1.4 times in the warm season and on the 7th day it was 535 and 580 thous. units per $\mathrm{m}^{3}$, respectively.
\end{abstract}

Keywords: Microclimate; Poultry litter; Accumulation time; Humidity; Cage battery; Air contamination

\section{Introduction}

Intensive technologies of poultry production are based on the use of modern poultry crosses with high laying capacity and the ability to effectively use the nutrients from the feed. One of the important issues that often arise in the production process of such enterprises is the accumulation of a large amount of litter. Due to the high content of organic matter, the litter of laying hens can be not only a valuable organic fertilizer, but also a raw material for biogas plants (Chaump et al., 2019; Dornelas et al., 2017). But most poultry farms, for some reason, do not have new technologies that can effectively utilize the poultry litter for profit.

Fresh poultry litter is a viscous substance with a moisture content of $64-82 \%$ depending on the species, age of the bird, feeding and keeping conditions (Dunlop et al., 2016). Fresh litter contains organic and inorganic substances. Inorganic substances include water, some compounds of nitrogen (ammonia, nitrates), copper, phosphorus, potassium, zinc, calcium and manganese. Organic 
substances include nitrogenous compounds (proteins, peptides and amino acids), carbon compounds (lipids, glycerols, fatty acids, carbohydrates, including cellulose, sugars, alcohols, volatile acids and cellulosolignin) and sulfuric compounds (sulfides). Litter may also contain antibiotics, heavy metal salts, radionuclides, pesticide residues and other toxic substances that can adversely affect the environment (Douglas et al., 2016).

The basic chemical composition of the native litter with a humidity of $72 \%$ is as follows: solids $27.8 \pm 3.18 \%$; ash $20.1 \pm 2.1 \%$ (including calcium up to 8.5\%; phosphorus 1.6-2.0\%); crude fat $4.8 \pm 1.81 \%$; crude protein $26.58 \pm 6.52 \%$; crude fiber $14.89 \pm$ $2.01 \%$ and organic matter $79.9 \pm 2.1 \%$ (Yaremchuk et al., 2012). It is known that the body of laying hens uses about $53 \%$ of nitrogen from the feed. The crude litter contains $0.8-1.2 \%$ of nitrogen. Fresh nitrogen is found in the form of urea, urine and hippuric acids, amino and amino acids, protein substances and some other compounds. Depending on the storage conditions and shelf life, nitrogen losses can be as high as 40\% (Nahm, 2003; Ogejo \& Collins, 2009).

The value of litter as an organic fertilizer is determined primarily by the content of such substances as nitrogen (1.3-1.7\% $\mathrm{N}$ ), phosphorus $\left(1.6-2.0 \% \mathrm{P}_{2} \mathrm{O}_{5}\right)$, potassium $\left(0.5-0.8 \% \mathrm{~K}_{2} \mathrm{O}\right)$ (Chen \& Jiang, 2014). Many litter substances decompose easily under the influence of light, atmospheric air, moisture, enzymes and microorganisms (Abumere et al., 2019).

The litter removed from the poultry house often contains viable weed seeds, larvae and helminth eggs as well as microorganisms, including pathogens (Enticknap et al., 2006; Paliy et al., 2018). Therefore, in order to prevent negative impact on the ecosystem, the use of raw, not decontaminated litter as a fertilizer is prohibited by the current Veterinary and Sanitary Rules for poultry farms and other regulatory documents.

Under natural aeration and humidity conditions, the microbial contamination of the litter can reach very large values and have a significant impact on the ecology of the area. For example, $1 \mathrm{~g}$ of litter sometimes contains more than 1 billion ammoniating bacteria. In addition to oxidizing agents, the litter contains thermophilic, nitrophilic, denitrophic bacteria and pathogens of various ferments (cellulose, pectic, butyric acid, lactic acid, etc.), molds, actinomycetes and yeast (Chen et al., 2015; Kim et al., 2012; Lopes et al., 2013).

The amount of litter released by a bird per day depends on the species, breed, age of the bird, feeding characteristics, microclimate in the poultry house and other factors (Henuk \& Dingle, 2003).

The data on the amount and humidity of the litter produced by one bird per day are quite controversial in the scientific and technical literature (Ta'nczuk et al., 2019; Tan et al., 2019).

According to the current normative standards of technological designing of poultry enterprises in Ukraine (BHTП-АПК-04.05, Departmental Technological Design Standards for Agro-Industrial Complex-04.05), the following standards of daily litter production and its humidity are established: when keeping adult egg laying hens - 155-160 g and 71-73\%, meat chickens - $165 \mathrm{~g}$ and also $71-$ $73 \%$, turkeys - $450 \mathrm{~g}$ and $64-66 \%$, geese $-594 \mathrm{~g}$ and $80-82 \%$ and ducks $-423 \mathrm{~g}$ and $80-82 \%$. The production of broiler litter when growing the poultry up to the age of 5 weeks in cage batteries is $100 \mathrm{~g}$ on average over the period; when growing up to the age of 6 weeks on the floor, it is $120 \mathrm{~g}$, litter moisture is $64-74 \%$.

Litter output data, specified in the departmental standards of technological design, are applied for the design of systems for disposal, storage and processing of litter at poultry enterprises. Therefore, if they are unreliable, businesses can suffer significant losses: if the standards are overstated - due to the excess of the required costs for these systems; if they are underreported - due to lack of adequate capacity, the litter will be used irrationally, and may also pose a threat to the ecology of the region. Significant differences in the litter output indicators are reported in Departmental Standards of Technological Design in Agro-Industrial Complex-04.05 and in various sources of scientific and technical information (Bolanet et al., 2010; Esenamanova et al., 2018) and (НТП АПК 1.10.05.011-01, Technological Design Standards for AIC 1.10.05.011-01) suggest the further study of this issue.

Reduction in the humidity of the litter in the poultry houses is of paramount importance worldwide as it largely depends on the preservation of nutrients, the microclimate of the premises, as well as the costs of subsequent transportation and processing of this product, and the environmental impact (Bolan et al., 2010; Ghaly \& Alhattab, 2013).

The humidity of both raw and bed litter is largely influenced by the type and rations of feeding the poultry, the drinking bowl used, the microclimate in the poultry house, etc. (Ishchenko et al., 2019; Mohamed et al., 2010).

The problem of wet litter occurs when feeding poultry with a sodium content of more than $0.28 \%$. It is recommended to introduce sodium in the diet in the amount of $0.15-0.25 \%$. When feeding poultry with feed containing toxic substances or thirst-enhancing ingredients, the moisture of the litter also increases. Additives to the diet of foods high in fiber (such as wheat bran) help to reduce the humidity of bird droppings. The development of mold on wet feeds results in the accumulation of mycotoxins, which also increase water consumption and, thus, litter moisture (Essam et al., 2018; Nagornaya, 2019).

At the same time, the actual data on the effect of the time of accumulation of litter on the belts of cages batteries on its humidity, chemical composition and microclimate in the poultry house is rather scarce and this issue requires more detailed study.

\section{Materials and Methods}

The study of the kinetics of the drying of the litter and the impact of its accumulation on the belt conveyors of cage batteries on the chemical composition of excrement and microclimate in the poultry house was carried out in four standard poultry houses, $18 \times 96$ m in size. 4-tier 'Hellmann' cage batteries (Germany) with built-in air ducts and without such ducts were used for keeping laying hens. The stock density in the poultry houses was $29.5-30.7$ heads $/ \mathrm{m}^{2}$.

The poultry were fed on full-feed granulated compound feeds according to the feeding standards recommended by the bird supplier. The microclimate parameters were monitored and maintained in accordance with the recommendations for keeping hens of this cross.

The studies were conducted in cold and warm seasons. The time of accumulation of litter on the belt conveyors of cage batteries when performing the studies was 7 days.

The dynamics of the litter humidity, the change in its chemical composition, the microclimate parameters in the poultry houses, depending on the time of excretion accumulation on the belt conveyors of the cage batteries, were determined by different systems of litter removal. Litter samples to determine humidity and chemical composition were taken once a day during the entire litter accumulation period (7 days) at the same time in six locations of the poultry house. When carrying out chemical analyzes of the litter, the moisture content (according to the State Standard GOST 26713-85), nitrogen (according to the State Standard GOST 26715-85), potassium (according to the State Standard GOST 26718-85), phosphorus (according to the State Standard GOST 26717-85) were determined.

The microclimate parameters (temperature and relative humidity, content of ammonia, hydrogen sulfide and carbon dioxide and microbial contamination) were determined once a day at the same time, from 9 am to $11 \mathrm{am}$, by standardized methods (Balanin, 1988) at 3 
different points diagonally in the poultry house (at the beginning, middle and end of the cage area) at the level of the first and fourth tiers of cage batteries.

The temperature and relative humidity were determined using an MB-4M aspiration psychrometer. The content of ammonia, carbon dioxide and hydrogen sulfide was determined using a universal gas analyzer UG-2.

To determine the microbial contamination, the air from the poultry house was sampled using a Krotov apparatus, followed by the introduction of a sample of air on Petri dishes with prepared meat-peptone agar (MPA). Sampling was carried out for 5 minutes with an aspiration rate of $30 \mathrm{l} / \mathrm{min}$. Petri dishes with selected samples were placed into a thermostat for 24 hours at an air temperature of $37^{\circ} \mathrm{C}$, after which the number of colonies was calculated using a device for counting colonies of bacteria.

Statistical processing of research results was performed according to conventional methods, using application software for Windows OS: Microsoft Excel.

\section{Results and Discussion}

The results of the study of the kinetics of drying the litter on the belts of cage batteries for keeping laying hens depending on the season and the type of batteries are shown in Figure 1.

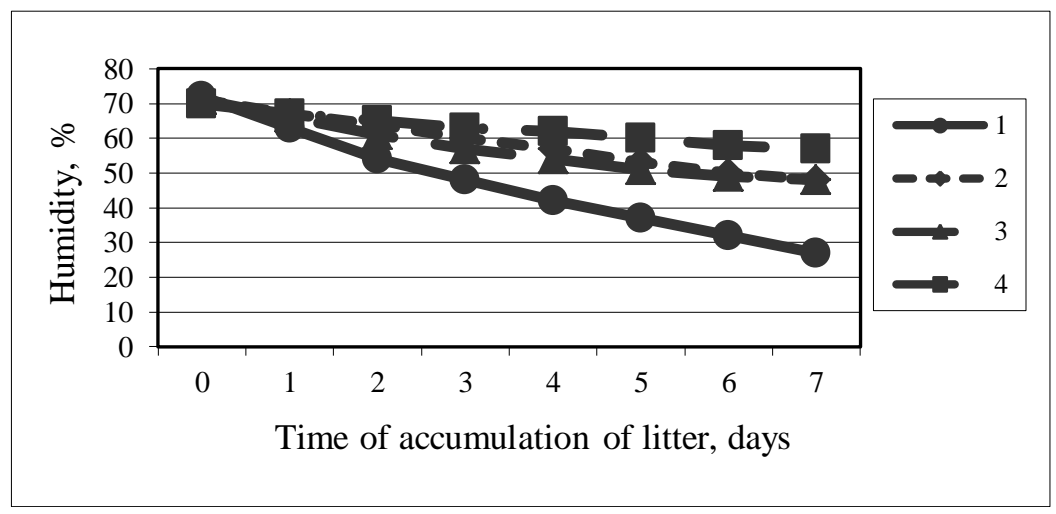

Figure 1. Dependence of litter humidity on the time of the accumulation on the belt conveyors of cage batteries: 1 - cage batteries with built-in air ducts in the warm season; 2 - cage batteries without built-in air ducts in the warm season; 3 - cage batteries with built-in ducts in the cold season; 4 - cage batteries without built-in air ducts during the cold season.

It was found that both when using the cage batteries with the ventilation system of belts and without it in the summer provided a higher degree of drying of the litter, which is explained by the higher air temperature in the poultry house and that of the air supplied by the ducts during this period. In winter the air temperature in the air ducts was from 10 to $20^{\circ} \mathrm{C}$ (average about $16^{\circ} \mathrm{C}$ ), but in summer it reached $28^{\circ} \mathrm{C}$ in separate periods.

In turn, a much higher level of litter drying was observed when using cage batteries with a belt ventilation system. The initial humidity of the litter was $66.9-72.6 \%$. As a rule, the average accumulation time of litter on belt conveyors in poultry farms is 5 days. In winter, when using cage batteries with air ducts during this period, the humidity of the litter decreased to an average of $53 \%$, in the summer - to 37\%; when using cage batteries without air ducts - to 58 and $49 \%$, respectively. However, on the particular coldest days, the humidity of the litter was reduced even less.

The volume of air supplied by the ducts was constant at the level of $0.7 \mathrm{~m}^{3} / \mathrm{h}$ per 1 head. But the air temperature in the duct and the proportion of fresh air in it varied depending on the temperature and humidity of the air outside.

To prevent the condensation of the moisture from the air, the temperature of the air supplied through the ducts of the litter drying system must be higher than the moisture condensation temperature under these conditions - air temperature in the poultry house, temperature and humidity of the external air.

The regulation of the ratio of the fresh air and the air from the poultry house going to the recirculation in the equipment used was carried out with the help of a climate computer.

According to the results of this experiment, it was recommended to intensify the process of drying the litter on the belt conveyors with built-in air ducts in the cold season, to insulate the air mixing chamber and install a heater for heating the air supplied. The camera was insulated by lining it with bricks with a layer of thermal insulation material (mineral wool) $10 \mathrm{~cm}$ thick. A $10 \mathrm{~kW}$ gas air heater was installed to heat the air in the air mixing chamber, which provided the heating of the inlet air by $2-3^{\circ} \mathrm{C}$ and allowed to increase the propotion of the fresh air supplied through the ducts. The dynamics of drying the litter in the cold season on the belt conveyors of cage batteries with a standard system of ventilation of belts and with an upgraded one are shown in Figure 2 . 


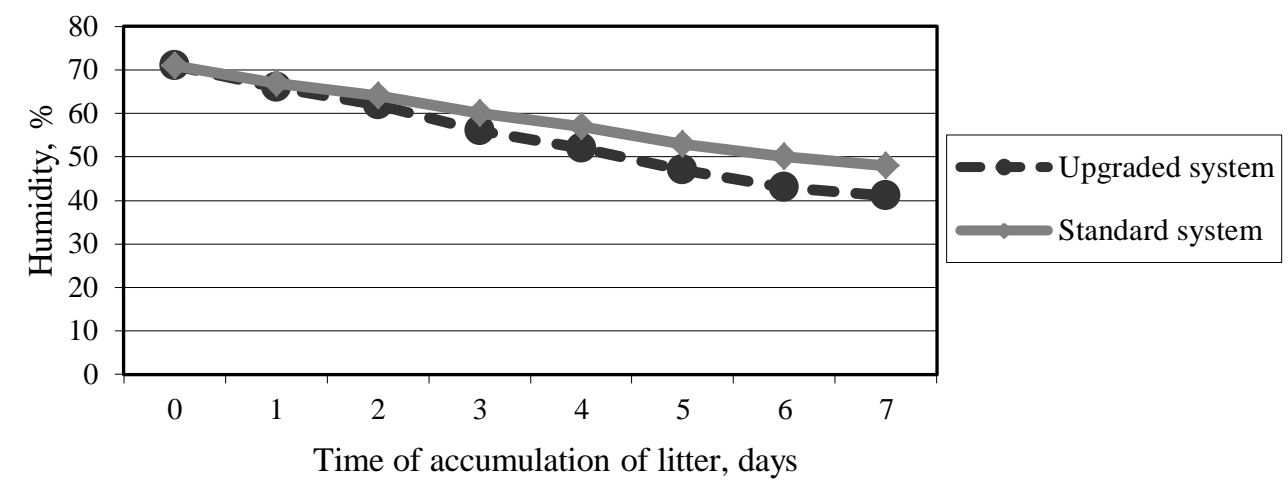

Figure 2. Dependence of the humidity of the litter on the accumulation time on the belt conveyors of the cage batteries when using a standard and upgraded air mixer.

Tests of the upgraded litter drying system have shown that it reduces the litter humidity by $6 \%$ after 5 days and $7 \%$ after 7 days of its accumulation on the belt conveyors, compared to the standard system.

In the warm season, the air heater in the air mixer chamber was not used, and its thermal insulation did not have a significant effect on the dynamics of drying the litter.

The results of the studies of the effect of the time of accumulation of litter on the belts of the cage batteries of different types on the microclimate in poultry houses are shown in Tables 1-3.

Table 1. Microclimate parameters in the poultry houses, depending on the time of accumulation of litter on the belts of cage batteries without built-in air ducts.

\begin{tabular}{|c|c|c|c|c|c|}
\hline \multirow[t]{2}{*}{ Microclimate parameter } & \multirow{2}{*}{$\begin{array}{c}\text { Units of } \\
\text { measuremen } \\
t\end{array}$} & \multicolumn{4}{|c|}{$\begin{array}{l}\text { Days of accumulation of litter on the belts of cage } \\
\text { batteries }\end{array}$} \\
\hline & & 1 & 3 & 5 & 7 \\
\hline \multicolumn{6}{|c|}{ Cold season } \\
\hline Air temperature & ${ }^{\circ} \mathrm{C}$ & $21.3 \pm 0.54$ & $21.1 \pm 0.72$ & $21.5 \pm 0.39$ & $21.2 \pm 0.37$ \\
\hline Relative humidity & $\%$ & $65.7 \pm 1.8$ & $65.7 \pm 2.1$ & $65.3 \pm 2.3$ & $65.5 \pm 1.6$ \\
\hline Ammonia content in the air & $\mathrm{mg} / \mathrm{m}^{3}$ & $7.1 \pm 0.53$ & $11.6 \pm 0.47$ & $14.4 \pm 0.46$ & $17.3 \pm 0.37$ \\
\hline $\begin{array}{l}\text { Carbon dioxide content in the } \\
\text { air* }\end{array}$ & $\%$ & $0.11 \pm 0.0043$ & $\begin{array}{l}0.13 \pm \\
0.0035 \\
\end{array}$ & $\begin{array}{l}0.14 \pm \\
0.0054\end{array}$ & $0.16 \pm 0.0039$ \\
\hline $\begin{array}{l}\text { Hydrogen sulfide content in } \\
\text { the air }\end{array}$ & $\mathrm{mg} / \mathrm{m}^{3}$ & - & - & 1 & 1 \\
\hline \multicolumn{6}{|c|}{ Warm season } \\
\hline Air temperature & ${ }^{\circ} \mathrm{C}$ & $24.3 \pm 0.44$ & $23.8 \pm 0.39$ & $24.6 \pm 0.49$ & $26.3 \pm 0.48$ \\
\hline Relative humidity & $\%$ & $55.3 \pm 1.5$ & $60.2 \pm 2.3$ & $61.7 \pm 1.7$ & $60.7 \pm 1.6$ \\
\hline Ammonia content in the air & $\mathrm{mg} / \mathrm{m}^{3}$ & $5.5 \pm 0.37$ & $7.2 \pm 0.47$ & $10.5 \pm 0.63$ & $15.2 \pm 0.66$ \\
\hline $\begin{array}{l}\text { Carbon dioxide content in the } \\
\text { air* }\end{array}$ & $\%$ & $0.05 \pm 0.0038$ & $\begin{array}{l}0.06 \pm \\
0.0053\end{array}$ & $\begin{array}{l}0.08 \pm \\
0.0046 \\
\end{array}$ & $0.10 \pm 0.0039$ \\
\hline $\begin{array}{l}\text { Hydrogen sulfide content in } \\
\text { the air }\end{array}$ & $\mathrm{mg} / \mathrm{m}^{3}$ & - & - & - & - \\
\hline
\end{tabular}

Note: $*$ - in the table below, carbon dioxide content is given as a percentage (\%) by volume.

During the cold season, the air exchange in the poultry houses was maintained at the level of $0.7-1.2 \mathrm{~m}^{3} / \mathrm{h}$ of air per $1 \mathrm{~kg}$ of live weight of the poultry. The microclimate control computer maintained the set temperature and humidity parameters in an automated mode, so they remained practically the same throughout the period of accumulation of litter on the belt conveyors. At the same time, ammonia content in the air increased with the increase in the time of accumulation of the litter; and after 5 days of accumulation in the cold season its level began the maximum contamination level - $15 \mathrm{mg}$ per $1 \mathrm{~m}^{3}$ of air. The amount of ammonia on the 7th day of the accumulation of the litter in all the poultry houses exceeded its amount in the first day of accumulation by 1.82.8 times $(P \leq 0.001)$.

Ammonia and carbon dioxide content in the poultry house with built-in ducts in the cage batteries in the cold season in the first 4 days of accumulation of litter was higher than in the poultry houses with caged batteries without ducts, since part of the air of the poultry house with high concentration of these gases was directed into the recirculation while in the poultry house with cage batteries without air ducts a fresh air was fed all the time.

Table 2. Microclimate parameters in the poultry houses, depending on the time of accumulation of litter on the belt conveyors of cage batteries with built-in air ducts and a standard air preparation system. 


\begin{tabular}{|l|c|c|c|c|c|}
\hline \multicolumn{7}{|c|}{ Cold season } \\
\hline Air temperature & ${ }^{\circ} \mathrm{C}$ & $21.4 \pm 0.29$ & $21.9 \pm 0.46$ & $21.2 \pm 0.58$ & $21.3 \pm 0.29$ \\
\hline Relative humidity & $\%$ & $65.4 \pm 2.5$ & $65.7 \pm 2.3$ & $65.6 \pm 1.8$ & $65.3 \pm 2.3$ \\
\hline Ammonia content in the air & $\mathrm{mg} / \mathrm{m}^{3}$ & $9.3 \pm 0.36^{* *}$ & $12.7 \pm 0.44$ & $15.2 \pm 0.62$ & $17.1 \pm 0.55$ \\
\hline $\begin{array}{l}\text { Carbon dioxide content in the } \\
\text { air }\end{array}$ & $\%$ & $\begin{array}{c}0.14 \pm 0.0023 \\
* * *\end{array}$ & $\begin{array}{c}0.16 \pm \\
0.0034 \\
* * *\end{array}$ & $0.16 \pm 0.0039 *$ & $\begin{array}{c}0.16 \pm \\
0.0028\end{array}$ \\
\hline $\begin{array}{l}\text { Hydrogen sulfide content in } \\
\text { the air }\end{array}$ & $\mathrm{mg} / \mathrm{m}^{3}$ & - & - & - & 1 \\
\hline \multicolumn{7}{|c|}{ Warm season } \\
\hline Air temperature & ${ }^{\circ} \mathrm{C}$ & $24.5 \pm 0.45$ & $23.4 \pm 0.48$ & $24.7 \pm 0.62$ & $26.2 \pm 0.57$ \\
\hline Relative humidity & $\%$ & $55.3 \pm 1.9$ & $60.2 \pm 2.0$ & $61.7 \pm 1.9$ & $60.5 \pm 2.3$ \\
\hline Ammonia content in the air & $\mathrm{mg} / \mathrm{m}^{3}$ & $5.1 \pm 0.34$ & $6.9 \pm 0.28$ & $8.9 \pm 0.44$ & $13.7 \pm 0.36$ \\
\hline $\begin{array}{l}\text { Carbon dioxide content in the } \\
\text { air }\end{array}$ & $\%$ & $0.05 \pm 0.0046$ & $\begin{array}{c}0.05 \pm \\
0.0035\end{array}$ & $0.07 \pm 0.0047$ & $0.08 \pm$ \\
\hline $\begin{array}{l}\text { Hydrogen sulfide content in } \\
\text { the air }\end{array}$ & $\mathrm{mg} / \mathrm{m}^{3}$ & - & - & - & - \\
\hline
\end{tabular}

Notes: * $-\mathrm{P} \leq 0.05 ; * *-\mathrm{P} \leq 0.01 ; * * *-\mathrm{P} \leq 0.001$ (compared to the same season when using cage batteries without air ducts). However, since ammonia emissions from the litter with a higher humidity was greater than that from the drier litter, ammonia content in the air of the poultry house cage batteries without air ducts grew faster than in poultry house with the cage batteries with ducts. Therefore, from the fifth day of accumulation of the litter, the ammonia content in the air of the first poultry house began to exceed its content in the air of the second poultry house.

In the warm season in the poultry house with cage batteries with ducts, the air from the poultry house was not directed to the air mixer, so the content of ammonia and carbon dioxide in this poultry house was slightly lower than when using cage batteries without ducts due to the greater emission gases from the wetter litter in the latter case.

A small amount of hydrogen sulfide in the air was observed only in the last days of the accumulation of litter: when using cage batteries with built-in ducts - on the 7th day, without ducts - starting from the 5th day.

Modernization of the air mixer did not significantly affect the temperature and relative humidity of the poultry house in the cold season, as these parameters were maintained automatically. However, the ammonia and carbon dioxide content of the air in the poultry house with the upgraded cold mixer in the cold season significantly decreased compared to the standard one, due to the greater ratio of fresh air mixed with the poultry air supplied through the air ducts of the litter drying line: ammonia - by 1.15-1.24 times and carbon dioxide - by 1.23-1.27 times.

In summer, the temperature in the poultry houses was higher and the humidity lower than in winter. The air exchange was maintained at the level of $5-6 \mathrm{~m}^{3} / \mathrm{h}$ per $1 \mathrm{~kg}$ of live weight of the poultry. The process of drying the litter was more intense than in the winter due to higher air temperature and more intense air exchange. The concentration of ammonia in the air of the poultry houses in the summer was lower than in the winter for the same reason - due to significantly higher air exchange. At the same time, a similar tendency was observed - to increase its number with increasing accumulation of the litter.

Table 3. Microclimate parameters in the poultry houses, depending on the time of accumulation of litter on the belts of cage batteries with built-in ducts and upgraded air mixer.

\begin{tabular}{|c|c|c|c|c|c|}
\hline \multirow[t]{2}{*}{ Microclimate parameter } & \multirow{2}{*}{$\begin{array}{c}\text { Units of } \\
\text { measuremen } \\
t\end{array}$} & \multicolumn{4}{|c|}{$\begin{array}{l}\text { Days of accumulation of litter on the belts of cage } \\
\text { batteries }\end{array}$} \\
\hline & & 1 & 3 & 5 & 7 \\
\hline \multicolumn{6}{|c|}{ Cold season } \\
\hline Air temperature & ${ }^{\circ} \mathrm{C}$ & $21.2 \pm 0.47$ & $21.3 \pm 0.55$ & $21.5 \pm 0.57$ & $21.5 \pm 0.36$ \\
\hline Relative humidity & $\%$ & $65.2 \pm 2.3$ & $65.5 \pm 1.9$ & $65.6 \pm 1.8$ & $65.7 \pm 2.0$ \\
\hline Ammonia content in the air & $\mathrm{mg} / \mathrm{m}^{3}$ & $7.7 \pm 0.44 * *$ & $11.0 \pm 0.41 *$ & $12.7 \pm 0.50 * *$ & $14.1 \pm 0.45^{* *}$ \\
\hline $\begin{array}{l}\text { Carbon dioxide content in the } \\
\text { air (by volume) }\end{array}$ & $\%$ & $\begin{array}{c}0.11 \pm \\
0.0034 \\
* * *\end{array}$ & $\begin{array}{c}0.12 \pm \\
0.0052 \\
* * *\end{array}$ & $\begin{aligned} 0.13 & \pm 0.0038 \\
& * * *\end{aligned}$ & $\begin{array}{c}0.13 \pm 0.0043 \\
* * *\end{array}$ \\
\hline $\begin{array}{l}\text { Hydrogen sulfide content in } \\
\text { the air }\end{array}$ & $\mathrm{mg} / \mathrm{m}^{3}$ & - & - & - & - \\
\hline \multicolumn{6}{|c|}{ Warm season } \\
\hline Air temperature & ${ }^{\circ} \mathrm{C}$ & $23.9 \pm 0.43$ & $22.5 \pm 0.42$ & $23.4 \pm 0.51$ & $24.3 \pm 0.47$ \\
\hline Relative humidity & $\%$ & $54.2 \pm 1.6$ & $59.2 \pm 2.3$ & $63.1 \pm 1.6$ & $58.9 \pm 2.2$ \\
\hline Ammonia content in the air & $\mathrm{mg} / \mathrm{m}^{3}$ & $7.1 \pm 0.31$ & $9.5 \pm 0.44$ & $12.5 \pm 0.52$ & $13.9 \pm 0.53$ \\
\hline $\begin{array}{l}\text { Carbon dioxide content in the } \\
\text { air (by volume) }\end{array}$ & $\%$ & $\begin{array}{l}0.05 \pm \\
0.0036\end{array}$ & $\begin{array}{l}0.06 \pm \\
0.0056\end{array}$ & $0.05 \pm 0.0039$ & $0.06 \pm 0.0052$ \\
\hline $\begin{array}{l}\text { Hydrogen sulfide content in } \\
\text { the air }\end{array}$ & $\mathrm{mg} / \mathrm{m}^{3}$ & - & - & - & - \\
\hline
\end{tabular}

Notes: * $-\mathrm{P} \leq 0.05 ; * *-\mathrm{P} \leq 0.01 ; * * *-\mathrm{P} \leq 0.001$ (compared to the same season when using a standard air mixer).

With an increase in the time of accumulation of litter on belt conveyors of cage batteries, an increase in microbial air contamination was also observed (Figure 3). 


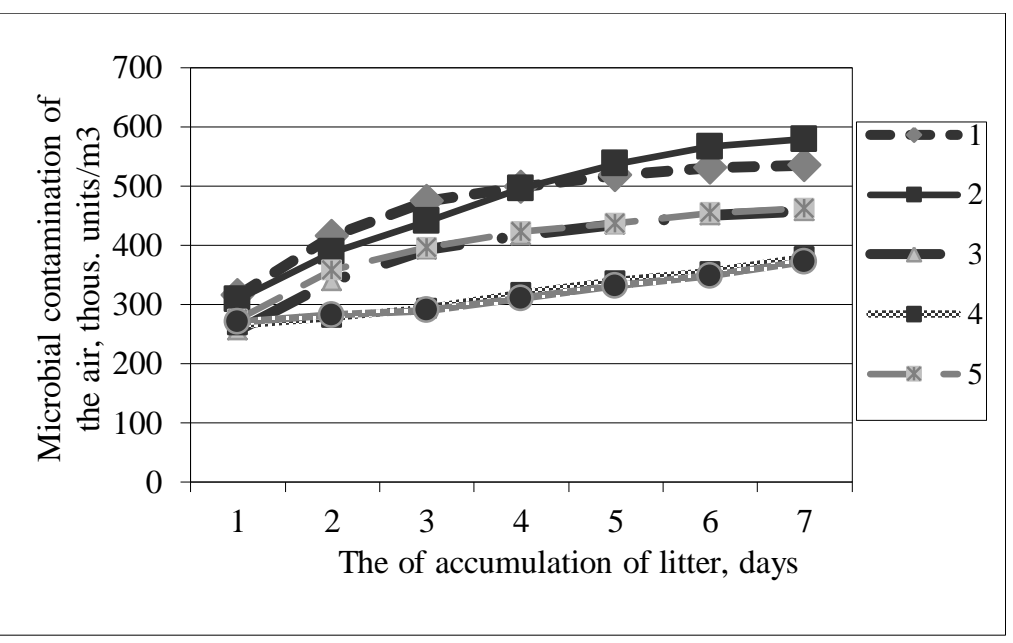

Figure 3. Microbial air contamination in the poultry houses equipped with cage batteries with a belt conveyor system: 1 - cage batteries with built-in air ducts in the cold season; 2 - cage batteries without built-in air ducts in the cold season; 3 - cage batteries with built-in ducts and upgraded air mixers in the cold season; 4 - cage batteries with built-in ducts during the warm season; 5 cage batteries without built-in ducts during the warm season; 6 - cage batteries with built-in ducts and upgraded air mixer during the warm season.

When using cage batteries without built-in air ducts, from the 1st to the 7th day of accumulation microbial air pollution increased by 1.9 times in the cold and 1.7 times in the warm seasons. When cage batteries with built-in ducts were used, microbial air contamination increased slightly less: by 1.7 times during the cold season and 1.4 times during the warm period. Higher microbial air contamination when using cell batteries without a drying system in the last days of litter accumulation, in our opinion, is due to the fact that the wetter litter is makes better conditions for the microorganisms to live in. Upgrading the air mixer made it possible to reduce the microbial contamination of the air in the poultry house (by 1.17-1.23 times) for the same reason as the content of toxic gases due to the increase in the proportion of fresh air in the mixture supplied through the ducts.

In all cases, microbial air contamination exceeded the maximum permissible veterinary and sanitary standards for poultry farms (ВНТП-АПК-04.05, Departmental Technological Design Standards for AIC-04.05) level (220 thous. units per $1 \mathrm{~m}^{3}$ of the air in the poultry houses) by 1.2-2.6 times, which indicates the need for developing measures to reduce it. Such measures could include: installation of filters, bactericidal lamps in the air mixers, treatment of the supplied air with disinfectant aerosols and the like.

The chemical composition of the litter, depending on the time of accumulation in the cold season, is shown in Table 4.

Table 4. Dependence of the chemical composition of the litter on the accumulation time on the belt conveyors of cage batteries.

\begin{tabular}{|c|c|c|c|}
\hline \multirow{2}{*}{$\begin{array}{l}\text { Time of accumulation of } \\
\text { litter on the belts, days }\end{array}$} & \multicolumn{3}{|c|}{ Content in terms of absolutely dry substance,\% } \\
\hline & Nitrogen & Phosphorus & Potassium \\
\hline \multicolumn{4}{|c|}{ Cage batteries with air ducts and standard air mixers } \\
\hline Fresh litter & $4.87 \pm 0.034$ & $2.86 \pm 0.042$ & $1.78 \pm 0.029$ \\
\hline 1 & $4.81 \pm 0.031$ & $2.87 \pm 0.038$ & $1.77 \pm 0.033$ \\
\hline 2 & $4.83 \pm 0.028$ & $2.86 \pm 0.035$ & $1.79 \pm 0.026$ \\
\hline 3 & $4.69 \pm 0.030 * *$ & $2.88 \pm 0.045$ & $1.67 \pm 0.037$ \\
\hline 4 & $4.70 \pm 0.041^{* *}$ & $2.84 \pm 0.037$ & $1.81 \pm 0.038$ \\
\hline 5 & $4.62 \pm 0.037^{* * *}$ & $2.81 \pm 0.043$ & $1.76 \pm 0.041$ \\
\hline 6 & $4.57 \pm 0.033^{* * *}$ & $2.84 \pm 0.039$ & $1.78 \pm 0.034$ \\
\hline 7 & $4.53 \pm 0.031^{* * *}$ & $2.83 \pm 0.042$ & $1.77 \pm 0.039$ \\
\hline \multicolumn{4}{|c|}{ Cage batteries with air ducts and modernized air mixers } \\
\hline Fresh litter & $4.81 \pm 0.034$ & $2.97 \pm 0.032$ & $1.82 \pm 0.028$ \\
\hline 1 & $4.77 \pm 0.028$ & $2.93 \pm 0.039$ & $1.82 \pm 0.033$ \\
\hline 2 & $4.73 \pm 0.043$ & $2.89 \pm 0.041$ & $1.78 \pm 0.043$ \\
\hline 3 & $4.68 \pm 0.037$ & $2.95 \pm 0.039$ & $1.85 \pm 0.037$ \\
\hline 4 & $4.69 \pm 0.051$ & $2.88 \pm 0.036$ & $1.90 \pm 0.035$ \\
\hline 5 & $4.71 \pm 0.041$ & $2.90 \pm 0.037$ & $1.82 \pm 0.028$ \\
\hline 6 & $4.59 \pm 0.037 * *$ & $2.94 \pm 0.042$ & $1.85 \pm 0.036$ \\
\hline 7 & $4.55 \pm 0.038^{* *}$ & $2.93 \pm 0.028$ & $1.85 \pm 0.039$ \\
\hline \multicolumn{4}{|c|}{ Cage batteries without air ducts } \\
\hline Fresh litter & $4.76 \pm 0.041$ & $2.93 \pm 0.033$ & $1.80 \pm 0.026$ \\
\hline 1 & $4.64 \pm 0.039$ & $2.91 \pm 0.037$ & $1.80 \pm 0.029$ \\
\hline 2 & $4.58 \pm 0.037^{*}$ & $2.93 \pm 0.042$ & $1.81 \pm 0.033$ \\
\hline 3 & $4.50 \pm 0.038 * *$ & $2.93 \pm 0.039$ & $1.79 \pm 0.041$ \\
\hline 4 & $4.47 \pm 0.043 * *$ & $2.90 \pm 0.045$ & $1.82 \pm 0.035$ \\
\hline 5 & $4.42 \pm 0.037^{* * *}$ & $2.91 \pm 0.033$ & $1.80 \pm 0.037$ \\
\hline 6 & $4.39 \pm 0.029 * * *$ & $2.90 \pm 0.039$ & $1.82 \pm 0.027$ \\
\hline 7 & $4.37 \pm 0.035^{* * *}$ & $2.89 \pm 0.040$ & $1.82 \pm 0.033$ \\
\hline
\end{tabular}

Notes: * $-\mathrm{P} \leq 0.05 ; * *-\mathrm{P} \leq 0.01 ; * * *-\mathrm{P} \leq 0.001$ (compared to the fresh litter for this variant). 
The tendency to decrease the total nitrogen content in the litter with increasing the litter accumulation time on the belt conveyors was established. Thus, during the 7-day period of accumulation of litter in the cage batteries without air ducts, the nitrogen content decreased by $0.39 \%$, with built-in air ducts and the standard system of drying the litter - by $0.34 \%$, with the upgraded system of drying the litter - by $0.26 \%$. The content of phosphorus and potassium has changed slightly and these changes have been observed mainly due to a decrease in the relative nitrogen content.

Thus, based on the above, we can conclude the need for the development of techniques aimed at reducing the emission of ammonia and microbial air contamination in the poultry houses and make a stress on the possible positive impact of their application on the productive performance of the poultry and the environmental status on the whole. The solution of this problem for the cold season is of particular importance (Sarada et al., 2017).

Depending on the technology of keeping the poultry and the equipment used, there is a certain period of accumulation and temporary storage of the litter in the poultry house. With modern technologies for keeping poultry on the litter bed, litter is usually stored throughout the breeding or keeping cycle of the poultry (Teixeira et al., 2015). In broiler farming this period is 5-10 weeks; when keeping grown up hens, it is up to one year or more (Wei et al., 2015).

According to the normative technological parameters of poultry breeding and keeping, the humidity of the litter bed is $15-40 \%$ (Dunlop et al., 2015). However, in the case of insufficient amount of litter bed, excess stock density, failure to comply with the required microclimate parameters, the humidity of the litter can significantly increase, which negatively affects the microclimate in the poultry house, the survival, productive and reproducible performance of the poultry (Dumas et al., 2011; Miles et al., 2011).

The humidity of the litter during keeping in cages is greatly influenced by the equipment used, especially the type of drinking bowls. With the use of gutter drinking bowls, the water consumption increases by about $50 \%$ and the moisture content of the litter by $2-8 \%$ compared to the use of nipple bushings. The water flowing from the drinking bowls necessarily goes one way or another into the litter, increasing its humidity even more (Paliy \& Ishchenko, 2019).

It was found that both when using cage batteries without the ventilation system of litter conveyors, and with them, in the cold season the intensity of drying the litter was much lower than in the warm season; and in some, the coldest periods, it decreased even more. This was due to the lower temperature and lower air flow through the ducts and into the poultry house during this period. In winter the air temperature in the ducts was about $16^{\circ} \mathrm{C}$, but in summer it reached $28^{\circ} \mathrm{C}$ in some periods, the volume of air supplied by the ducts was $0.7 \mathrm{~m}^{3} / \mathrm{h}$ per 1 head. In turn, a much higher level of litter drying was observed when using cage batteries with a belt ventilation system. The content of ammonia, carbon dioxide and microbial air contamination in the poultry house with ventilated conveyor belts in the cold season during the first 4 days of litter accumulation was higher than in the poultry house with cage batteries without air ducts, since some of the contaminated air in the poultry house was sent to the recirculation station while fresh air was supplied all the time to the cage batteries with no air ducts. However, as more ammonia nitrogen was lost from the humid litter faster than from the dry onr, ammonia content in the air of the poultry house with cage batteries without air ducts grew faster than in that with cage batteries with air ducts. Therefore, since the fifth day of the accumulation of the litter, the ammonia content in the air of the first poultry house began to exceed its content in the air of the second poultry house. In the warm season, the content of toxic gases when using cage batteries with ventilated belts was lower because the air of the house was not sent for recirculation.

Despite the continuous improvement of technological means and techniques for the preparation of litter and pollutant emissions into the atmosphere, the problem of reliable ecological protection of nature objects (water, air and soil) remains as urgent as ever and requires a solution. Searching for and developing waste-free and environmentally friendly technological solutions for bioconversion of a poultry litter that will provide valuable nutrients from it are current trends in the development of modern science, which are of major economic and social importance.

\section{Conclusion}

It has been established that during the 7-day period of accumulation of litter on the belt conveyors of the cage batteries, ammonia content in the air increases by 1.8-2.8 times, reaching the level of $17.14-17.34 \mathrm{mg} / \mathrm{m}^{3}$ (MCL being $\left.15 \mathrm{mg} / \mathrm{m}^{3}\right)$ at the end of this period, the microbial contamination of the air of the poultry house grows by 1.4-1.9 times, exceeding MCL by $1.2-2.6$ times during the entire period of accumulation ( 220 thous. microbic units per $1 \mathrm{~m}^{3}$ ). The amount of carbon dioxide in the air increased by $1.14-$ 2.00 times, but it never exceeded $\mathrm{MCL}-0.25 \%$.

The additional thermal insulation of the air mixer and the installation of a $10 \mathrm{~kW}$ air heater enables to intensify the process of drying the litter on the belt conveyors of cage batteries (to reduce the moisture content of the litter compared to the standard system by $6 \%$ in 5 days, and by $7 \%$ in 7 days) to reduce nitrogen losses by $0.08-0.13 \%$, to reduce the ammonia content in the air of the poultry house by 1.15-1.24 times and microbial air contamination by 1.17-1.23 times.

\section{References}

Abumere, V. I., Dada, O.A., Adebayo, A.G., Kutu, F.R., \& Togun, A.O. (2019). Different Rates of Chicken Manure and NPK 15-15-15 Enhanced Performance of Sunflower (Helianthus annuusL.) on Ferruginous Soil. International Journal of Agronomy, 10. https://doi.org/10.1155/2019/3580562

Balanin, V.I. (1988). Zoohygienic control of the microclimate in livestock and poultry facilities. L.: Agropromizdat. (In Russian) Bolan, N.S., Szogi, A.A., Chuasavathi, T., \& Seshadri, B. (2010). Uses and management of poultry litter. World's Poultry Science Journal, 66(4), 673-698. https://doi.org/10.1017/S0043933910000656

Chaump, K., Preisser, M., Shanmugam, S.R., Prasad, R., Adhikari, S., \& Higgins, B. T. (2019). Leaching and anaerobic digestion of poultry litter for biogas production and nutrient transformation. Waste Manag., 84, 413-422. doi:10.1016/j.wasman

Chen, Z., \& Jiang, X. (2014). Microbiological safety of chicken litter or chicken litter-based organic fertilizer: a review. Agriculture, 4, 1-29. doi:10.3390/agriculture4010001

Chen, Z., Wang, H., Ionita, C., Luo, F., \& Jiang, X. (2015). Effects of chicken litter storage time and ammonia content on thermal resistance of desiccation-adapted Salmonella spp. Appl Environ Microbiol, 81, 6883-6889. doi:10.1128/AEM.01876-15

Dornelas, K.C., Schneider, R.M., \& do Amaral, A.G. (2017). Biogas from poultry waste-production and energy potential. Environ Monit Assess, 189(8), 407. doi:10.1007/s10661-017-6054-8

Douglas, A.R., Paulo, R.E., Analú, M., \& Kesia, S.L. (2016). Composition of Poultry Litter in Southern Brazil. Rev. Bras. Ciênc. Solo., 40. http://dx.doi.org/10.1590/18069657rbcs20140697 
Dumas, M.D., Polson, S.W., Ritter, D., Ravel, J., Jr, J.G., Morgan, R., \& Wommack, K.E. (2011). Impacts of Poultry House Environment on Poultry Litter Bacterial Community Composition. PLoS ONE 6(9), e24785.

https://doi.org/10.1371/journal.pone.0024785

Dunlop, M.W., Blackall, P.J., \& Stuetz, R.M. (2015). Water addition, evaporation and water holding capacity of poultry litter. Science of the Total Environment, 15(538), 979-985. doi:10.1016/j.scitotenv.2015.08.092

Dunlop, M.W., McAuley, J., Blackall, P.J., \& Stuetz, R.M. (2016). Water activity of poultry litter: Relationship to moisture content during a grow-out. Journal Environ Manage, 1(172), 201-206. doi:10.1016/j.jenvman

Enticknap, J.J., Nonogaki, H., Place, A.R., \& Hill, R.T. (2006). Microbial diversity associated with odor modification for production of fertilizers from chicken litter. Applied and environmental microbiology, 72, 4105-4114. doi:10.1128/AEM.02694-05

Esenamanova, M.S., Kuspangalieva, A.G., Dyusekenova, T.S., Esenamanova, J.S., \& Tlepbergenova, A.E. (2018). Biological processing of bird droppings to produce biogas and biofertilizer. International Journal of Applied and Basic Research, 11(1), 85-89. (In Russian)

Essam, S. Soliman, Nahla, H. Sallam, \& Eman, M. Abouelhassan. (2018). Effectiveness of poultry litter amendments on bacterial survival and Eimeria oocyst sporulation. Vet World, 11(8), 1064-1073. doi:10.14202/vetworld.2018.1064-1073

Ghaly, A.E., \& Alhattab, M. (2013). Drying poultry manure for pollution potential reduction and production of organic fertilizer. Am Journal Environ Science, 9, 88-102. doi:10.3844/ajessp.2013.88.102

Henuk, Y.L., \& Dingle, J.G. (2003). Poultry manure: source of fertilizer, fuel and feed. World's Poultry Science Journal, 59(3), 350360. doi:https://doi.org/10.1079/WPS20030022

Ishchenko, K.V., Palii, A.P., Kis, V.M., Petrov, R.V., Nagorna, L.V., Dolbanosova, R.V., \& Paliy, A.P. (2019). Investigation of microclimate parameters for the content of toxic gases in poultry houses during air treatment in the scrubber with the use of various fillers. Ukrainian Journal of Ecology, 9(2), 74-80.

Kim, J., Diao, J., Shepherd, M.W. Jr., Singh, R., Heringa, S.D., Gong, C., \& Jiang, X. (2012). Validating thermal inactivation of Salmonella spp. in fresh and aged chicken litter. Appl Environ Microbiol, 78, 1302-1307. doi:10.1128/AEM.06671-11

Lopes, M., Roll, V.F.B., Leite, F.L., Dai, Prá M.A., Xavier, E.G., Heres, T., \& Valente, B.S. (2013). Quicklime treatment and stirring of different poultry litter substrates for reducing pathogenic bacteria counts. Poult Science, 92, 638-644. doi:10.3382/ps.2012-02700 Miles, D.M., Rowe, D.E., \& Cathcart, T.C. (2011). High litter moisture content suppresses litter ammonia volatilization. Poultry Science Journal, 90(7), 1397-1405. doi:10.3382/ps.2010-01114

Mohamed, A.M., Sekar, S., \& Muthukrishnan, P. (2010). Prospects and Potential of Poultry Manure. Asian Journal of Plant Sciences, 9, 172-182. doi:10.3923/ajps.2010.172.182

Nagornaya, L. (2019). Trichothecene mycotoxins. Our Poultry Journal, 4(64), 58-60. (In Ukrainian)

Nahm, K.H. (2003). Evaluation of the nitrogen content in poultry manure. World's Poultry Science Journal, 59(1), 77-88.

doi:https://doi.org/10.1079/WPS20030004

Ogejo, J.A., \& Collins, E.R. (2009). Storing and handling poultry litter. Virginia Cooperative Extension publication, $442-054$.

http://pubs.ext.vt.edu/442/442-054/442-054.html

Paliy, A., \& Ishchenko, K. (2019). Proper water supply. Our Poultry Journal, 1(61), 34-35. (In Ukrainian)

Paliy, A.P., Sumakova, N.V., Mashkey, A.M., Petrov, R.V., Paliy, A.P., \& Ishchenko, K.V. (2018). Contamination of animal-keeping premises with eggs of parasitic worms. Biosystems Diversity, 26(4), 327-333. doi https://doi.org/10.15421/011848

Sarada, Prasanna Sahoo, Daljeet, Kaur, A.P.S. Sethi, A. Sharma, M. Chandra \& Chandrahas. (2017). Effect of chemically amended litter on litter quality and broiler performance in winter. Journal of Applied Animal Research, 45(1), 533-537.

https://doi.org/10.1080/09712119.2016.1150846

Ta'nczuk, M., Junga, R., Kolasa-Wiecek, A., \& Niemiec, P. (2019). Assessment of the Energy Potential of Chicken Manure in Poland. Energies, 12, 1244. doi:10.3390/en12071244

Tan, H.Q., Li, M., Jie, D.F., Zhou, Y.F., \& Li, X.A. (2019). Effects of different litters on ammonia emissions from chicken manure. International Journal of Agricultural and Biological Engineering, 12(4), 27-33. doi:10.25165/j.ijabe.20191204.5011

Teixeira, A.S., Oliveira, M.C., Menezes, J.F., Gouvea, B.M., Teixeira, S.R., \& Gomes, A.R. (2015). Poultry litter of wood shavings and/or sugarcane bagasse: animal performance and bed quality. Revista Colombiana de Ciencias Pecuarias, 28(3), $238-246$. doi:10.17533/udea.rccp.v28n3a4

Wei, F. X., Hu, X.F., Xu, B., Zhang, M. H., Li, S.Y., Sun, Q.Y. \& Lin, P. (2015). Genetics and Molecular Research, 14(2), $3160-3169$. doi:http://dx.doi.org/10.4238/2015.April.10.27

Yaremchuk, O.S., Zakharenko, M.O., \& Kurbatova, I.M. (2012). Chemical composition of litter of laying hens and features of its biofermentation under anaerobic conditions. Technology, 4 (113), 20-23. (In Ukrainian)

\section{Citation:}

Palii, A.P., Naumenko, O.A., Shkromada, O.I., Tarasenko, K.A., Rodionova, R.A., Nechyporenko, O.L., Nechyporenko, V.V., Ulko, L.Y., Ishchenko,K.V., Prudnikov, V.G., Paliy, A.P., Berezovskiy, A.V. (2019). Investigation of the Microclimate of Poultry Houses and Chemical Composition of Poultry Litter, Depending on the time of Its Accumulation in the Cage Batteries. Ukrainian Journal of Ecology, 9(3), $272-279$.

This work is licensed under a Creative Commons Attribution 4.0. License 